\author{
Contato \\ Av. Prof. Lineu Prestes, 338 \\ 05508-900 - Cidade Universitária - \\ São Paulo - Brasil \\ mspalmeira@gmail.com
}

\section{DOS EFEITOS DE UM EXÍLIO: MOSES FINLEY NA INGLATERRA*}

\author{
Miguel Soares Palmeira"
}

Universidade de São Paulo

São Paulo - São Paulo - Brasil

\title{
Resumo
}

Analisam-se aqui os significados da expatriação para a trajetória de Moses I. Finley (19121986), historiador de origem estadunidense ao qual se atribui um papel importante na reconfiguração dos estudos de História Antiga Greco-Romana na Inglaterra. Começa-se por uma caracterização do êxito acadêmico do personagem em questão, acompanhada de uma crítica à maneira como os pares de Finley ligam esse êxito à condição de exilado. Procede-se em seguida a uma descrição das condições da ida para a Inglaterra, em um primeiro movimento de apresentação dos traços pertinentes à compreensão da trajetória do historiador. A isso sucede um exame de certas marcas das obras de Finley do início dos anos 1950 que contribuem para regular sua inscrição no universo social dos classicistas da Inglaterra. Por fim, procura-se mapear constrangimentos e possibilidades postos a Finley devido à sua condição de "estrangeiro" (ou de historiador estrangeirado) no mundo acadêmico britânico, com o que se

\section{Palavras-chave}

espera invocar elementos de algum modo úteis para a discussão de tipos análogos de exílio.

Exílio de intelectuais - M. I. Finley - Estudos Clássicos.

* Bacharel e licenciado em História pela Universidade Federal Fluminense; doutor pelo programa de pós-graduação em História Social da Universidade de São Paulo. Professor do Departamento de História dessa mesma instituição.

** Todo o material de arquivo citado neste trabalho foi consultado com a autorização do master e dos fellows do Darwin College (Universidade de Cambridge). Sou grato a eles, bem como a Paul Millett (Downing College), por tornarem possível a realização da pesquisa em Cambridge. Versões preliminares deste texto foram comentadas por Carlos Augusto Machado, Fabio Andrioni, Franco Della Valle, Mariana Osés, Rafael Benthien e pelos alunos do curso "Problemas de história intelectual" (ministrado no Programa de Pós-Graduação em História Social da Universidade de São Paulo no $2^{\circ}$ semestre de 2012). Beneficiei-me igualmente das observações dos pareceristas anônimos da Revista de História. Agradeço especialmente a Francisco Murari Pires, orientador do trabalho que deu origem a este artigo. A pesquisa foi desenvolvida no âmbito do Programa de Pós-Graduação em História Social da Universidade de São Paulo, tendo sido financiada, em momentos distintos, pela Fundação de Amparo à Pesquisa do Estado de São Paulo/Fapesp e pela Coordenação de Aperfeiçoamento de Pessoal de Nível Superior/Capes. 


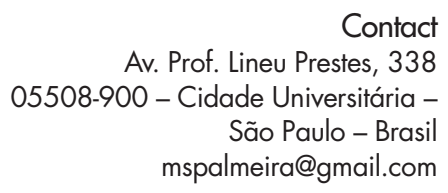

Contact

Av. Prof. Lineu Prestes, 338 05508-900 - Cidade Universitária São Paulo - Brasil mspalmeira@gmail.com

\section{HISTORIAN IN EXILE: MOSES FINLEY IN ENGLAND}

\author{
Miguel Soares Palmeira
}

Universidade de São Paulo

São Paulo - São Paulo - Brazil

\begin{abstract}
The present work analyses the meanings of expatriation in the trajectory of Moses I. Finley (1912-1986), an American historian who played an important role in the reconfiguration of the study of Greco-Roman Ancient History in England. The article begins with a characterization of Finley's academic "success", accompanied by a critique of how Finley's peers connect this success to his condition as ex-patriot. It then proceeds to describe the conditions of his move to England highlighting relevant features of Finley's trajectory. This is followed by an analysis of certain evidence in Finley's writings of the early 1950s that helped assure his acceptance in the social world of English classicists. Finally, the article maps both constraints and possibilities imposed on Finley due to his status as a "foreigner" (or foreignized historian) in the British academic world. The discussion ultimately hopes to advance useful elements for the comparative discussion of exile.
\end{abstract}

\title{
Keywords
}

Intellectual in exile - M. I. Finley - Classics. 
As discussões sobre aqueles que escrevem a história ou que se engajam em atividades semelhantes de criação intelectual reservam um lugar especial à figura do exilado. Trata-se de um topos que acompanha a própria constituição da historiografia como gênero, recuando a seus antecedentes clássicos, como lembra, evocando Tucídides e Heródoto, Antoon de Baets. ${ }^{1}$ Supõe-se frequentemente que a expatriação coagida (i. e. uma das formas possíveis de exílio), a despeito de sua natureza trágica, teria efeitos potencialmente benéficos tanto para os exilados quanto para a terra a que se destinam. No âmbito da historiografia contemporânea, o encontro do exilado com "culturas" distintas da sua de origem favoreceria perspectivas renovadas, fomentaria a sensibilidade comparativa, abriria horizontes. ${ }^{2}$

Tal senso comum foi reforçado à luz das experiências históricas do último século. As leis raciais do regime hitlerista (1933), seguidas da Segunda Guerra Mundial (1939-1945), ocasionaram uma diáspora científico-erudita cujos efeitos renovadores em universidades da Grã-Bretanha e sobretudo dos Estados Unidos alimentaram a imagem de um "privilégio epistemológico" do exilado (esta categoria conhecendo variações, das quais não poderei tratar aqui, como a do refugiado, do émigré, do outsider). É uma imagem renitente, que não parece ceder à constatação óbvia de que entre exílio e inovação intelectual não se dá uma relação de causa-efeito, ou seja, que a situação de exílio não instila em todos os seus protagonistas uma mesma "marginalidade criativa". ${ }^{3}$ Não será uma reafirmação de princípio quanto à impertinência dessa associação que fará a discussão avançar, como tampouco bastará a lembrança de que "exílio" é uma categoria demasiado genérica para designar situações muito variadas.

A alternativa que se persegue neste artigo passará por submeter a fórmula do outsider criativo à prova do exame empírico. Não se trata de simplesmente confirmar ou desmentir o privilégio ou a miséria do exilado, nem de balancear "perdas" e "ganhos" do país de origem e do país de destino, mas

\footnotetext{
1 DE BAETS, Antoon. Exile and acculturation: refugge historians since the Second World War. The International History Review, v. 28, n. 2, 2006, p. 316-349. Os trabalhos de síntese sobre história da historiografia dificilmente deixam de registrar a condição de "viajante" de Heródoto e de "exilado" de Tucídides. Cf., por exemplo, CARBONELL, Charles-Olivier. Historiografia. Lisboa: Teorema, 1987, p. 20-23.

2 DE BAETS, Antoon, op. cit. Em chave ensaística, a força do exílio como topos na história da literatura foi discutida por SAID, Edward. Reflexões sobre o exílio. In: Idem. Reflexões sobre o exílio e outros ensaios. São Paulo: Cia das Letras, 2003.

3 Conforme assinalou JEANPIERRE, Laurent. Une opposition structurante pour l'anthropologie structurale: Lévi-Strauss contre Gurvitch, la guerre de deux exilés français aux États-Unis. Revue d'histoire des sciences humaines, v. 2, n. 11, 2004, p. 13-43.
} 
de dimensionar o significado de um deslocamento - ensejado pela expatriação - no espaço social. Para tanto, trilha-se um caminho distinto do levantamento panorâmico - importante, diga-se - dos percursos de historiadores deslocados em consequência de repressão política. ${ }^{4}$ As interrogações deste texto serão levadas a cabo pelo estudo intensivo de parte da trajetória de Moses I. Finley (1912-1986), historiador de origem estadunidense radicado na Inglaterra em meados dos anos 1950. Com isso, espera-se, antes de mais nada, evitar certos volteios especulativos sobre a "experiência do exílio" e sobre a pulsão criativa que ela acarretaria - volteios que estimulam o cultivo de uma imagem fantasmática do criador intelectual autônomo, entregue a seus talentos. Em termos positivos, espera-se iluminar determinados aspectos da trajetória de Finley de maneira a repor a questão do exílio de intelectuais em termos históricos e sociológicos, explicitando a natureza das relações que se rompem e se refazem em tal experiência.

\section{Um outsider de prestígio}

O caso de Finley é interessante para pensar o problema acima delineado precisamente porque se trata de alguém cuja obra é, via de regra, pensada como efeito de um exílio. Vista em retrospecto, de fato a experiência de Finley como professor "exilado" afigura-se bem-sucedida, segundo padrões acadêmicos britânicos. A despeito de suas atividades como professor e pesquisador de História Antiga remontarem à primeira metade da década de 1930, foi somente a partir de 1955, ano da mudança definitiva para a Inglaterra, que sua atuação profissional se objetivou em postos e distinções acadêmicas de peso. Tendo passado por uma espécie de estágio como professor-palestrante convidado em Cambridge (setembro-dezembro de 1954) e Oxford (janeiro-março de 1955), Finley se estabeleceu em 1955 - aos 43 anos de idade, portanto - como lecturer in Classics na Universidade de Cambridge. Em 1964, tornou-se reader em história econômico-social do mundo antigo; e, em 1970, atingiu o cume da carreira universitária local, obtendo uma professorship. ${ }^{5}$ A reputação que acompanhava essa trajetória estendeu-se para além

\footnotetext{
${ }_{4}^{4}$ Veja-se um movimento nesse sentido em BENTLEY, Michael. Modern historiography. Londres: Routledge, 1999, p. 116-126.

5 A lectureship era o grau mais baixo de uma carreira acadêmica estável naquela instituição. Ingressar na Universidade nesse patamar não era algo evidente, pois professores de renome eram eventualmente contratados para ocuparem postos mais elevados; tampouco era evidente ir além da posição de lecturer (tornando-se reader ou professor), pois a evolução na carreira não
} 
do círculo profissional dos classicistas: entre outras expressões de reconhecimento fora de sua disciplina, Finley veio a ser membro da British Academy (a academia britânica de Humanidades e Ciências Sociais) em 1971, e foi feito cavaleiro do Império britânico, tornando-se sir Moses em 1979.

Na área que concentrou seus maiores investimentos, a história econômico-social, Finley esteve na linha de frente de um processo coletivo de sedimentação da ideia de que a economia da Antiguidade greco-romana, à diferença do que se passava nas sociedades industriais modernas, jamais foi percebida pelos antigos como um campo autônomo de experiências da vida social. A ordem metodológica daí decorrente, de construção de conceitos "apropriados à economia antiga, e não (ou não necessariamente) à nossa", ${ }^{6}$ estruturou debates ácidos dos anos 1970 em diante. Desde então, o nome "Finley" passou a ser frequentemente associado às formas de classificação das obras produzidas na área de "economia antiga", quando não literalmente adotado como uma unidade classificatória do campo (como é possível notar a partir dos anos 1990 na designação eventual de um novo tempo da historiografia econômica da Antiguidade clássica como "pós-Finley"). Na percepção dos pares, ele veio a personificar, para o bem ou para o mal, uma nova "escola" (com variações de rótulo: "primitivista", "minimalista", "cambridgeana", "weberiana" etc.) e a liderança de uma "nova ortodoxia" em história econômica antiga.

As insígnias de excelência e os epítetos associados a Finley repercutiam visões, entretidas a partir da década de 1970, desse historiador como figura central do campo da História Antiga. Desde então, no trabalho simbólico de elevação e reafirmação do pertencimento de Finley ao panteão dos "grandes homens" da profissão, é recorrente que se o retrate como alguém de sucesso ao mesmo tempo inequívoco e inusitado, com referências abundantes à sua condição de estrangeiro na Inglaterra e à qualidade de "excêntrico nos círculos classicistas", ${ }^{8}$ como dão a ver os trechos a seguir reproduzidos com ênfases minhas.

é ali uma decorrência necessária nem habitual do tempo no posto, mas, idealmente, uma recompensa ao mérito acadêmico.

6 FINLEY, Moses I. The ancient economy. Nova York: Penguin, 1992 [original 1973], p. 27.

7 Retomo neste parágrafo, de forma resumida, algo já desenvolvido na introdução de PALMEIRA, Miguel Soares. Moses Finley e a 'economia antiga': a produção social de uma inovação historiográfica. Tese de doutorado em História Social, Programa de Pós-Graduação em História Social, USP, São Paulo, 2008.

8 A formulação é de MORRIS, Ian. Foreword. In: FINLEY, M. I. The ancient economy. Los Angeles: University of California Press, 1999, p. xi. 


\section{Retratos de}

\section{um Historiador}

\section{"Estrangeiro"}

Os excertos selecionados (dentre os muitos similares possíveis) são da lavra de um contemporâneo e amigo de Finley (Momigliano); de um ex-aluno (Hornblower); de um historiador francês especializado em "economia antiga" (Bresson); e de um autor sem qualquer relação direta com o historiador cambridgeano (Janes). Não obstante tal diversidade, estão todos igualmente incumbidos de variedades de um discurso encomiástico (o balanço de uma obra exitosa; o prefácio à reedição de um "clássico"; um verbete de enciclopédia), nas quais é possível flagrar certas regularidades de produção e reiteração da imagem pública de Finley.

Quando veio da Universidade de Rutgers para a Inglaterra em 1954 como um refugiado da perseguição maccarthista, Moses Finley havia acabado de publicar seus Studies in land and credit in ancient Athens (1952) e estava prestes a publicar seu The world of Odysseus (1954). Juntos, esses dois livros mostravam que Finley era o melhor historiador social da Grécia vivo e o mais preparado para enfrentar os problemas que a história social implica. Isso foi reconhecido por um grupo restrito de especialistas que incluía os homens que lhe permitiram escolher entre Oxford e Cambridge (...). Mas nem mesmo seus mais calorosos apoiadores esperavam que em menos de vinte anos Finley se tornaria o historiador de História Antiga mais 
influente de sua época, igualmente respeitado e estudado em ambos os lados daquilo que se costumava chamar de Cortina de Ferro.?

Moses I. Finley foi um professor muito incomum de Oxbridge [amálgama de Oxford + Cambridge]. Ele era um exilado americano com um turbulento passado político de esquerda, um scholar sem educação formal em clássicos, cujos escritos agudos e inspiradores, contudo, viraram de cabeça para baixo os clássicos e a história grega antiga convencionais; um polemista público feroz que era também um professor excepcionalmente gentil e bem-humorado. ${ }^{10}$

Moses Finley foi um dos mais importantes historiadores da Antiguidade a emergir no mundo de língua inglesa nos últimos cinquenta anos. Embora natural dos Estados Unidos, Finley teve o efeito mais notável e dominante na Faculdade de Clássicos da Universidade de Cambridge, a qual, tanto à época como agora, era uma das mais importantes da Grã-Bretanha. Seu papel foi dar uma nova proeminência a questões sociais e econômicas na História Antiga e ao uso de modelos na resolução de problemas e controvérsias históricos. A razão disso pode residir em sua formação em Direito e História ao invés de em Estudos Clássicos tradicionais. A Grã-Bretanha precisa agradecer ao macarthismo pela mudança de Finley da Rutgers para Cambridge no início da década de $1950 .{ }^{11}$

A vida de Moses Immanuel Finley [sic] se confunde com um fascinante itinerário intelectual. (...) Feito cavaleiro em 1979 por seus méritos excepcionais, sir Moses Finley foi sem dúvida o mais europeu dos historiadores americanos. (...) Ele nasceu, todavia, nos Estados Unidos, e foi aí que teve toda sua formação. (...). Já atípico para um especialista da Antiguidade clássica, seu percurso conheceu uma nova inflexão devido ao macarthismo. Finley recusou curvar-se perante a caça às bruxas que então castigava os Estados Unidos, o que lhe valeu a perda de seu posto universitário. Ele decidiu se instalar na Inglaterra, onde permaneceu até o fim de seus dias. ${ }^{12}$

9 MOMIGLIANO, Arnaldo. The Greeks and us. The New York Review of Books, 16 de outubro de 1975, p. 36.

${ }^{10}$ HORNBLOWER, Simon. Introduction. In: FINLEY, M. I. The world of Odysseus. Londres: The Folio Society, 2002, p. xi. A grafia do termo professor em itálico indica a manutenção da palavra em inglês, em respeito à peculiaridade das conotações dessa palavra no universo estudado (cf. supra, nota 6).

${ }^{11}$ JANES, Dominic. Finley, Moses I. In: BOYD, Kelly (org.). Encyclopedia of Historians \& Historical Writing, vol. 1. Londres/Chicago: Fitzroy Dearborn Publishers, 1999, p. 385-386.

12 BRESSON, Alain. Moses Finley. In: SALES, Véronique Sales (org.). Les historiens. Paris: Armand Colin, 2003, p. 178-79. 
Embora seja evidente a relevância das origens e da formação de Finley para o entendimento de sua obra, a evocação dessas origens e de tal formação é normalmente feita nos marcos de uma representação idealizada da vida intelectual (aí subentendida a vida do personagem em questão). É como se a ida para a Inglaterra de um historiador estadunidense fosse um mero acidente, um desvio de curso que altera o meio no qual age esse historiador, mas preserva inalterada a natureza arrebatadora de sua ação. Nesse tipo de discurso, dados do mundo social em que Finley se moveu fazem incursões incidentais, como se desnecessários - ou, na melhor das hipóteses, secundários, razão pela qual assumem um caráter demasiado vago ou simplesmente anedótico - para elucidar as vicissitudes de uma carreira tida como fadada ao sucesso por um brilho infenso a coerções sociais de qualquer ordem.

Neste artigo, em vez de representar as posições sucessivamente ocupadas por Finley no mundo acadêmico como uma "história de vida" coerente e orientada para o êxito, confrontam-se, de um lado, as propriedades sociais e intelectuais acumuladas pelo historiador ao longo dos primeiros anos de carreira no exílio e, de outro, as feições de uma determinada configuração dos estudos clássicos na Inglaterra nos anos 1950 e 1960. Disso é possível depreender o caráter decisivo do exílio na Inglaterra, mas num sentido diverso daquele sugerido nos comentários deferentes ou acrimoniosos, que aquiescem igualmente diante da crença no historiador que se faz por si mesmo. Trata-se, ao contrário, de observar como a manipulação mais ou menos explícita, pelo próprio Finley e por seus pares, das qualidades de estrangeiro ou de exilado favorece os deslocamentos e as posições do historiador estadunidense no mundo dos scholars britânicos.

\section{Ida para a Inglaterra}

Quando foi convidado a passar alguns meses na Inglaterra no ano acadêmico de 1954-55, Finley havia angariado uma forma peculiar de notoriedade em razão das circunstâncias de sua demissão do posto de professor de História da Universidade de Rutgers (Nova Jersei). Um dos subcomitês do Senado dos Estados Unidos que no início dos anos 1950 investigavam "atividades antiamericanas" no país recebeu a denúncia de que, na década de 1930, Finley havia sido um dos organizadores de um grupo comunista em Nova York. Chamado a depor, o historiador se recusou a apontar comunistas entre os colegas pós-graduandos da Universidade de Columbia que frequentavam sua casa e se negou a responder se havia sido ele próprio um comunista nos anos 1930, invocando a Quinta Emenda da Constituição es- 
tadunidense (que confere a testemunhas o direito de não se autoincriminar em um processo penal). A menção a Finley como comunista por um segundo depoente ao Senado fez recrudescerem as pressões políticas para que a Rutgers o demitisse. A mesma investida se lançava contra Simon Heimlich, um matemático da Universidade, que também se valera da Quinta Emenda perante o mesmo subcomitê. O conselho diretor da universidade então condicionou a permanência dos dois professores no emprego à colaboração com a investigação oficial. Ante a recusa de ambos, a Rutgers os demitiu em $1^{\mathrm{o}}$ de janeiro de $1953 .^{13}$

Embora o macarthismo já se houvesse feito sentir em setores diversos da sociedade estadunidense e afetado intelectuais, o caso Finley-Heimlich era dos primeiros a implicar a Universidade e a pôr em xeque os limites de sua autonomia institucional. O New York Times deu cobertura extensa à discussão sobre a decisão dos administradores da Rutgers ao longo de janeiro de 1953. A resolução não custou apenas aos dois professores envolvidos no caso seus respectivos empregos a partir de 1 de janeiro de 1953: ambos eram, dali em diante, virtualmente não contratáveis por qualquer uma das universidades grandes ou médias dos Estados Unidos. O caráter público e emblemático que assumiu o processo da demissão tornava inviável que qualquer dessas instituições arcasse com o ônus de dar guarida a um professor por todos sabido suspeito de comunismo. O caso repercutiu também na imprensa inglesa pouco mais de um mês depois. O Manchester Guardian, um dos mais importantes diários ingleses, abriu espaço para um longo artigo anônimo sobre liberdade acadêmica nos Estados Unidos, publicado em duas partes, em 4 e 5 de março. ${ }^{14} \mathrm{~A}$ isto se seguiu uma intensa troca de cartas de Finley com classicistas de Oxford, Cambridge e Londres sobre o episódio da Rutgers. Já em 1954, diante do anúncio informal do convite para ministrar algumas palestras na Inglaterra, Finley diria a Anthony Andrewes, classicista britânico, haver se precipitado sobre ele tal avalanche de "gentileza e

\footnotetext{
13 Para a reconstituição desse processo, ver, principalmente, SCHRECKER, Ellen. No ivory tower: McCarthyism and the universities. Oxford: Oxford University Press, 1986, p. 3-11; 24-62. Cf. ainda VIDAL-NAQUET, Pierre. Karl Witfogel et la notion de mode de production asiatique: note liminaire. In: Idem. La démocratie grecque vue d'ailleurs. Paris: Flammarion, 1991, p. 267-276.

${ }^{14}$ An American debate. I - Heresy in the Common Room. Manchester Guardian, 4 de março de 1953; An American debate. II - Congress and the Colleges. Manchester Guardian, 5 de março de 1953.
} 
apoio de gente tanto de Oxford como de Cambridge" que sequer conseguia expressar seu reconhecimento. ${ }^{15}$

Ao mesmo tempo em que se tornava conhecido entre classicistas britânicos por vias inusitadas, Finley tinha seu nome a circular por vias convencionais. Sua tese de doutorado, publicada em 1952, começava a ser objeto de resenhas em periódicos especializados. Positivas ou negativas, as apreciações publicadas sobre o livro dão a ver um historiador em processo de afirmação: não bastasse o erro sintomático da grafia de seu nome em duas delas ("Moses L. Finley", num caso; "Moses I. Finlay", em outro), ${ }_{1}^{16}$ não há quaisquer referências aos trabalhos anteriormente publicados por Finley ou a sua atuação prévia como historiador de História Antiga, iniciada na primeira metade dos anos 1930. Até aquele momento, "Moses I. Finley" não era um nome que invocasse propriedades sociais típicas de um scholar de prestígio, por mais que resenhistas simpáticos de Land and credit lhe pespegassem o rótulo de "promissor". A experiência na Rutgers (1948-1952) fora a primeira dele como docente estável de uma universidade. Até então, havia trabalhado sob contrato temporário em instituições pouco prestigiosas do ensino superior americano (City College, Long Island University, Yeshiva College). Antes de 1952, suas únicas publicações eram dois artigos escritos em 1933-34, saídos em periódicos especializados, e resenhas ou ensaios bibliográficos sobre livros de História Antiga que apareceram em revistas e jornais dirigidos a um público de não especialistas (a maioria desses textos foi assinada com seu nome de nascença, Moses I. Finkelstein, que ele mudaria em 1946). E

\footnotetext{
${ }^{15}$ Carta datilografada a Anthony Andrewes em 2 de abril de 1954. Finley papers, box 16, G2. Os Finley papers (doravante FP) compõem-se de vinte caixas de arquivo que contêm um número variável de pastas onde se guardam parte da correspondência passiva e ativa do historiador, recortes de jornal, folhas avulsas com notas sobre textos antigos e modernos, rascunhos de textos, separatas de publicações, entre outros itens. Esse material foi em grande parte organizado pelo próprio historiador, tendo sido reclassificado depois de sua morte pelo helenista italiano Ricardo di Donato. Ele se encontra atualmente sob os cuidados da seção de manuscritos da biblioteca central da Universidade de Cambridge. Para uma discussão a respeito da constituição desse "arquivo pessoal", cf. PALMEIRA, Miguel. Arquivos pessoais e história da história: a propósito dos Finley papers. In: TRAVANCAS, Isabel; ROUCHOU, Joëlle; HEYMANN, Luciana (org.). Arquivos pessoais: reflexões multidisciplinares e experiências de pesquisa. Rio de Janeiro: Ed. FGV, 2013, p. 79-99.

${ }^{16}$ Trata-se, respectivamente, de JONES, Arnold Hugh Martin. Resenha de Studies in land and credit. The Economic History Review, new series, v. 6, n. 3, 1954, p. 316-317; e de De STE. CROIX, Geoffrey Ernst Maurice. Resenha de Studies in land and credit. The English Historical Review, v. 68, n. 268, 1953 , p. 450-451. Ambos os autores (especialmente o primeiro) terminariam por ser decisivos na mudança de Finley para a Inglaterra.
} 
tendo obtido o grau de doutor apenas em 1950, ele chegava à Inglaterra sem ter jamais orientado uma tese ou arregimentado discípulos. Quaisquer que fossem seus méritos como historiador, eles ainda não se haviam, portanto, cristalizado em sinais externos de excelência.

Embora os discursos solenes repitam frequentemente que em 1954 Finley já era "o melhor historiador social da Grécia vivo"17 e embora seus méritos como scholar por certo importassem, o que o levou à Inglaterra em 1954 foi fundamentalmente uma solidariedade de corporação. $\mathrm{O}$ auxílio a acadêmicos perseguidos politicamente não era prática desconhecida de profissionais de universidades inglesas e americanas que estivessem em atividade por mais de uma década. A mobilização de uma cadeia de solidariedade tinha sido frequente entre professores universitários nos Estados Unidos e na Inglaterra depois de 1933, quando foram banidos das instituições de ensino superior alemãs (e italianas, em 1938) professores de origem judaica.

Dadas aquelas circunstâncias, a posição inicial do historiador estadunidense no universo da classical scholarship britânica era precária, própria de alguém que mal se fizera conhecer pelos novos pares e que ainda lutava para ser por eles reconhecido. Por outro lado, nos anos seguintes, a história da demissão de Finley - sua não capitulação diante das pressões inquisitórias do Senado - não deixaria de repercutir nas representações correntes da vida e da obra desse scholar. Entre estudantes e nas porções progressistas do mundo universitário, o exílio fez de Finley uma figura heroica, ${ }^{18}$ a quem supostamente desagradava falar sobre o próprio passado. Isto excitou uma longa cadeia de comentadores a se voltarem para este passado, ora em chave mistificadora, ora em termos de uma biografia intelectual propriamente dita (não sendo incomum a mistura entre biografia e mistificação). ${ }^{19}$

\footnotetext{
17 Trata-se de uma formulação de MOMIGLIANO, Arnaldo, op. cit., p. 36, seguida por, entre outros, SHAW, Brent $\mathcal{E}$ SALLER, Richard. Editors' Introduction. In: FINLEY, M. I. Economy and society in ancient Greece. Londres: Chatto $\mathcal{E}$ Windus, 1981, p. ix; e WHITTAKER, C. R. Moses Finley, 1912-1986. Proceedings of the British Academy, v. 94, 1997, p. 464.

18 "Naqueles anos [início da década de 1970], Finley era uma grande referência para a história econômica e social da Antiguidade. Seu 'exílio' na Inglaterra, devido ao macarthismo nos Estados Unidos, fazia dele, para nós, uma figura heroica". HARTOG, François. La chambre de veille. Entretiens avec Felipe Brandi et Thomas Hirsch. Paris: Flammarion, 2013, p. 19-20.

${ }^{19}$ A resistência a tratar de seu passado americano, especialmente do episódio da Rutgers, é recorrentemente aludida nos registros biográficos de Finley. Vale mencionar duas reiterações recentes disso. A primeira está na introdução de um importante dossiê dedicado à obra do historiador: "desde sua chegada à Inglaterra em 1954, Finley evitou falar muito sobre seu passado". (NAIDEN, F. S. E TALBERT, Richard. Introduction. American Journal of Philology,
} 


\section{Das relações de crédito ao mundo de Ulisses}

Finley foi incorporado à classical scholarship em situação distinta da de seus colegas alemães, herdeiros desterrados da matriz histórica da profissão. Sua constituição como scholar, que seus dois primeiros livros materializavam, dava-lhe características peculiares, que mesclavam uma erudição clássica convencional investida num campo de estudos de pouco prestígio na Inglaterra - a história econômica antiga - e a abordagem heterodoxa de um tópico canônico - a poesia homérica.

Studies in land and credit in ancient Athens, originalmente preparado como tese de doutorado na Universidade de Columbia, era seu primeiro trabalho de fôlego em História Antiga. Tratava-se de um estudo das relações de crédito em Atenas entre 500 e 200 a. C. baseado nos horoi, inscrições gravadas em pedras hipotecárias para indicar a obstrução jurídica de uma determinada parcela da propriedade de um devedor. Finley fazia uma análise estatística de 144 dessas inscrições, combinada com o exame de passagens de discursos de oradores atenienses relativas a disputas judiciais em torno da propriedade da terra, para determinar a função social dos horoi, terminando por apontar uma estrutura de crédito concebido e praticado com propósitos não produtivos - na contramão do que supunha a visão então predominante entre estudiosos do Direito na Grécia antiga. ${ }^{20}$ À luz da direção tomada pela carreira do autor dali em diante, era um trabalho atípico. Alguns de seus traços - justamente aqueles que funcionavam como signos de pertencimento ao universo da classical scholarship - não se reproduziriam em livros posteriores: a utilização de uma documentação primordialmente epigráfica, as longas no-

\footnotetext{
special issue: Moses Finley in America. The making of an ancient historian, vol. 135, n. 2, 2014, p. 169. DOI: 10.1353/ajp.2014.0014). A segunda se encontra em um trabalho de Daniel Tompkins (a quem se deve o grosso das informações de que dispomos hoje sobre a vida de Finley nos EUA): "Finley raramente discutia seu passado, mesmo com seus amigos britânicos..."; "Finley era sabidamente reticente quanto a seu passado" (TOMPKINS, Daniel. The making of Moses Finley. In: JEW, Daniel; OSBORNE, Robin; SCOTT, Michael (org.). M. I. Finley. An ancient historian and his impact. Cambridge: Cambridge University Press, 2016, p. 13). A rigor, as circunstâncias da ida de Finley para a Inglaterra eram um tema recorrente em entrevistas para a imprensa. A um jornal local de estudantes da Universidade (o Varsity), por exemplo, ele não se furtou a comentar sua saída da Rutgers em ao menos duas ocasiões: 22 de abril de 1961 (p. 3) e 20 de novembro de 1965 (p. 7). É preciso, portanto, qualificar melhor as circunstâncias de discrição e de loquacidade associadas a esse historiador.

${ }^{20}$ FINLEY, Moses I. Studies in land and credit in ancient Athens. The horos inscriptions. New Brunswick: Transactions Books, 1985 [orig. 1952]. Para a novidade trazida por esse trabalho, ver WHITTAKER, op. cit.
} 
tas de citações em grego e latim, as passagens em alemão, italiano e francês também não traduzidas (a figurar, por vezes, no corpo do texto), a publicação de anexos contendo a documentação estudada (na qual o autor propunha a sua própria tradução dos horoi) etc. Tal aparato técnico doravante apareceria, quando muito, em artigos publicados pelo autor em revistas especializadas. Boa parte de sua produção consistiria a partir de então em livros dirigidos a um público não acadêmico ou em artigos e livros que, embora de feitio acadêmico, tinham um escopo e uma circulação que não se ajustavam às linhas estabelecidas de um espaço de saber institucionalizado dos classicistas. ${ }^{21}$

Uma assinatura própria, isto é, um estilo retórico, analítico e expositivo apareceria em The world of Odysseus, publicado nos Estados Unidos simultaneamente à chegada do historiador à Inglaterra e reeditado em Londres dois anos depois. ${ }^{22}$ Pensado inicialmente como capítulo introdutório de um livro maior sobre a civilização grega, Odysseus ganhou vida própria em 1953 para se tornar, à vista do autor, o "retrato de uma sociedade", suas instituições e seus valores. Nele, o autor concilia observações históricas sobre os poemas homéricos - origem, autoria, data da fixação por escrito etc. - com uma espécie de antropologia do mundo "grego" dos séculos X e IX a. C. Tal receita é administrada sem as marcas de um texto técnico dos Estudos Clássicos. As inúmeras citações da Ilíada e da Odisseia são feitas todas no corpo do texto, já traduzidas. Há poucas referências e citações a livros e artigos fora do ensaio bibliográfico que fecha o livro, e elas são assinaladas por asteriscos, ao invés de notas numeradas. Não se enuncia a respeito dos poemas uma tese central (embora ali houvesse muitas pequenas teses), não se prefacia o livro para explicar sua estrutura, não se dá necessariamente crédito a argumentos alheios - em outras palavras, não se perfazem os atos rotinizados pelos quais ali se reconheceria um livro acadêmico em sentido estrito. ${ }^{23}$

\footnotetext{
${ }^{21}$ Nos vinte anos seguintes à publicação de Land and credit, Finley publicou 27 textos sob forma de artigos, capítulos de livros e textos de conferências em atas de congressos. Desses, mais da metade (16) apareceu em publicações não especializadas em História Antiga. Isto pode ser observado a partir da lista de títulos publicados da lavra de Finley preparada por Brent Shaw e Richard Saller ao final de sua edição de FINLEY, Moses I. Economy and society in ancient Greece. Londres: Chatto \& Windus, 1981.

${ }^{22}$ FINLEY, Moses I. The world of Odysseus. Nova York: The New York Review of Books, 2002 [orig. 1954].

${ }^{23}$ Finley escreveria a seu editor um ano antes da publicação: “Creio que o produto final será um livro legível, em que trabalhos acadêmicos recentes (...) em vários campos serão levados em conta. Mas não será um livro acadêmico [scholarly book] no sentido estrito de se argumentar pró e contra cada ponto, apresentar outros pontos de vista, acumular notas de pé-de-página, essas coisas". Carta a Pascal Covici em 24 de outubro de 1953. Finley papers, box 2, A29.
} 
A sociedade homérica era concebida como organizada em torno de oikoi, isto é, casas em sentido amplo, a compreender família, agregados, terras e bens em geral; dessa organização derivavam a satisfação das necessidades materiais, as normas éticas e os valores, os deveres e as responsabilidades, as relações sociais e as relações com os deuses. À medida que Finley avançava em Odysseus na caracterização desse mundo, os tópicos canônicos da literatura sobre Homero - as "observações históricas" acima mencionadas - se esvaíam, em benefício de uma vasta apropriação de noções e autores naquele momento estranhos ao horizonte de preocupações dos helenistas anglo-saxões. Cumpria um papel particularmente significativo a referência ao fenômeno da troca de presentes observado (direta ou indiretamente) por antropólogos em populações indígenas da Polinésia, da Melanésia e do noroeste americano. Assim como nessas sociedades, no mundo em que se movia Ulisses, personagem da Ilíada e protagonista da Odisseia, os bens eram frequentemente postos em circulação à maneira de dádivas - aparentemente gratuitas, mas em realidade interessadas - que geravam a obrigação social de retribuir (não necessariamente de imediato) o presente recebido. Dádiva e contradádiva eram mecanismos fundamentais das relações estabelecidas entre diferentes oikoi (convivendo com uma lógica redistributiva que presidia as práticas econômicas dentro de cada oikos).

Apostava-se, então, no exame das instituições e dos valores como mais revelador da sociedade homérica do que os fatos aduzidos a partir da crítica filológica ou dos achados arqueológicos. Embora a aproximação entre História Antiga e Antropologia não fosse algo propriamente original, ela traduzia uma postura heterodoxa em relação aos estudos homéricos da época, o que era magnificado pelo fato de nessa área se travarem então as mais acirradas discussões da classical scholarship. Por volta de 1954-55, Homero e os poemas atraíam a atenção de eruditos sob o impacto da decifração, por dois professores de Cambridge (John Chadwick e Michael Ventris), das inscrições gravadas em tabuinhas de argila do período micênico (1400-1200 a. C.). O idioma que ali se revelava ("Linear B") tinha traços semelhantes ao grego homérico, favorecendo inicialmente a ideia de que o mundo representado na Ilíada e na Odisseia era aquele da civilização micênica e que, por conseguinte, o cerco de uma liga aqueia contra a cidade de Troia tematizado na Ilíada havia de fato ocorrido. No momento em que as primeiras descobertas de Chadwick e Ventris vinham à luz, Odysseus terminava de ser redigido. A princípio de forma discreta, depois de modo incisivo (a partir da $2^{\text {a }}$ edição revista, em 1956), seu argumento caminhava em direção contrária à visão dominante dos que viam em Homero o relato de uma grande guerra da Era do Bronze. 
Finley entendia que a parte até então decifrada do texto dizia respeito não aos "gregos" - isto é, não às populações iletradas a que se referia Homero e cujo desenvolvimento histórico levaria à formação da cidade-estado -, mas a uma espécie de sociedade organizada em torno de palácios, dotada de um aparato burocrático análogo ao de monarquias próximo-orientais (visão que terminaria por se impor como dominante nas décadas seguintes).

Esse foi um cavalo de batalha de Finley em seus primeiros tempos em Cambridge. Mais do que a tese de doutorado e sua prometida, porém jamais realizada, sequência - uma série de estudos sobre práticas de negócios em Atenas -, foi Odysseus o produto intelectual do historiador mais pleno de implicações para sua inserção no universo social dos classicistas britânicos. Nos anos 1950 (ainda que certamente não apenas aí), Homero era uma das paradas importantes nos percursos acadêmicos de helenistas de Cambridge e Oxford. Com efeito, apesar de a programação da estada de Finley na Inglaterra em 1954-55 prever cursos e palestras sobre outros assuntos, a chamada "questão homérica" terminou por se impor como problema central das atividades do historiador durante aquela viagem.

Uma consequência do livro [Odysseus] é que eu tenho me envolvido em algumas discussões informais sobre Homero, algo que eu jamais poderia antecipar um ano atrás. Na verdade, meu último ato "oficial" na Inglaterra será uma fala sobre posse da terra em Homero no seminário que Turner e Webster têm conduzido em Londres sobre o Linear B. Tenho feito uma campanha ativa pela minha visão de que o Linear B reflete um mundo claramente diferente do homérico, e tenho tido muito apoio por aqui. Londres, creio eu, é o centro da oposição, de modo que a tarde deverá ser interessante. ${ }^{24}$

A tomada de posição de Odysseus repercutiria nos anos seguintes, com Finley a empreender sua "campanha ativa" para provar que o mundo micênico não era grego no sentido que Homero emprestava a esse termo. O livro, ao arrepio de sua fatura inicial, academicizava-se, com a edição inglesa de 1956 incluindo um apêndice sobre os tabletes micênicos (escrito pelo próprio autor) e um prefácio legitimador de Maurice Bowra, classicista de Oxford estudioso de Homero (o prefácio americano havia ficado a cargo de Mark

\footnotetext{
${ }^{24}$ Carta a Friderich Solmsen (classicista alemão radicado nos EUA) em 25 de fevereiro de 1955 (FP, box 2, A30). Finley faz referência a E. G. Turner e T. B. L. Webster, que conduziam à época um seminário sobre o Linear B no Classical Institute (Universidade de Londres). Finley tornaria a polemizar com Webster em uma resenha de um livro deste autor publicada em um jornal de grande circulação: FINLEY, Moses I. What set Homer writing? The Daily Telegraph, 8 de agosto de 1958, p. 10 (a propósito de From Mycenae to Homer: a study in early Greek literature).
} 
Van Doren, um crítico literário midiático). O "mundo de Ulisses" e a Era do Bronze constituíam-se provisoriamente em temas centrais de um historiador cujos interesses principais incidiam "praticamente desde o início... [sobre] o direito e a economia da Antiguidade [clássica, em especial]". ${ }^{25}$

A "questão homérica" assim contribuía para demarcar um espaço no qual se moveria o historiador. Note-se que os limites desse espaço não eram traçados apenas pelas opiniões substantivas de Finley sobre Homero, mas, sobretudo, por um modo peculiar de sustentar essas opiniões. As perguntas do livro faziam dos poemas homéricos materiais expressivos de um sistema de valores. Este não poderia ser desvendado pelos procedimentos ordinários de uma crítica histórica interessada em distinguir fantasia e fatos, mas por uma abordagem que fizesse da fantasia o fato. Assim, pago, no começo do livro, o tributo a uma tradição classicista de leitura dos poemas, operava-se uma série de transgressões dessa tradição pelo recurso a certa antropologia (sobretudo aquela derivada de Malinowski) e a certa sociologia (de matriz durkheimiana) e pelo diálogo constante com Karl Polanyi. Não foi por acaso que Louis Gernet reconheceu de imediato que os problemas de métodos levantados pela obra tinham uma significação sociológica. ${ }^{26}$

\section{As consequências da migração}

A ida para a Inglaterra representou uma dupla mudança no estatuto profissional de Finley. Em primeiro lugar, ele migrava de um campo periférico de estudos - a História Antiga nos Estados Unidos, em geral abrigada nos departamentos de História das universidades daquele país - para um campo central - a História Antiga na Grã-Bretanha, não vinculada diretamente à Históriadisciplina, mas dominada nas instituições socialmente mais importantes (Oxford e Cambridge) por uma outra unidade institucional e simbólica, os Classics.

Em segundo lugar, os diferentes pesos institucionais dos Estudos Clássicos nos Estados Unidos e na Inglaterra desdobravam-se na diferença de importância relativa dos classicistas de ambos os países em âmbito internacional. Ao longo do século XX, mas especialmente em sua primeira metade, os classicistas estadunidenses viram-se frequentemente classificados no métier - fosse por eles próprios ou por colegas de outros países - como profissionais

\footnotetext{
${ }^{25}$ Material publicitário enviado à imprensa para divulgação de Studies in land and credit em abril de 1952 (FP, box 2, A24).

${ }^{26}$ GERNET, Louis. Resenha de The world of Odysseus. Année Sociologique, 3 a série, v. 7, 1953-54, p. 295-297.
} 
menores, desprovidos de tradição na disciplina e herdeiros apenas indiretos do patrimônio cultural greco-romano. Face aos pares estadunidenses, os classicistas britânicos estiveram, desde a institucionalização dos Clássicos como disciplina universitária, em uma posição de autoridade, na qual ambas as partes reconheciam o poder efetivo de julgar os frutos da produção intelectual sobre os antigos e, mais importante, de eleger o virtuosismo linguístico como critério fundamental dessa espécie de juízo. O problema da língua está no centro das percepções das dificuldades dos Clássicos nos Estados Unidos, onde se penou "com o fracasso de muitas escolas no ensino de línguas" e onde, portanto, "inimigos da erudição exata" encontram guarida e "retóricos talentosos" se estabelecem "como gurus locais". ${ }^{27}$ Com a balança de prestígio a pender nesses termos em favor dos classicistas britânicos, a ida para a Universidade de Cambridge de um ex-professor de uma universidade média dos Estados Unidos, que apenas começava a se fazer conhecido em seu meio profissional, ungia-o de uma nova espécie de legitimidade, alterando as condições da eficácia de seu discurso no mundo social dos classicistas.

Era, de todo modo, uma migração insólita. Tanto mais porque, mesmo para o padrão estadunidense, o percurso profissional de Finley era em alguma medida atípico - à primeira vista em um sentido francamente positivo, mas carregado também de handicaps importantes. Objeto de um forte investimento familiar, a educação de Moses foi pontuada por feitos de um prodígio: aos 11 anos de idade, o ingresso na universidade (saudado pelo Washington Post em setembro de 1923 como êxito do mais jovem estudante de graduação da história dos Estados Unidos); aos 15 anos, a formatura (magna cum laude) em Psicologia (major), Francês e Inglês (minor); aos 17, a conclusão do mestrado em Direito. A ascensão meteórica, entretanto, não se reverteria em empregos estáveis. Feita a conversão ao estudo das Humanidades após seu fastio com uma breve carreira jurídica, Finley teve de se haver com as persistentes restrições impostas aos judeus nesse setor da vida acadêmica estadunidense dos anos $1930 .^{28}$ Transitou então por atividades diversas, algumas importantes em sua formação intelectual e sua socialização acadêmica,

\footnotetext{
${ }^{27}$ A frase é de Hugh Lloyd Jones, classicista de Oxford, e foi citada por HALLETT, Judith P. Writing as an American in classical scholarship. In: HALLETT, J. P. \& NORTWICK, Th. Van (org.). Compromising traditions. The personal voice in classical scholarship. Londres: Routledge, 1997, p. 136-137.

${ }^{28}$ Os judeus enfrentavam dificuldades especialmente nos processos de seleção dos departamentos de Inglês e de História, porções do mundo universitário que se arvoravam em guardiãs do "espírito americano", como observa NOVICK, Peter. That noble dream. The "objectivity question" and American historical profession. Cambridge: Cambridge University Press, 1988, p. 172-74. Os entraves
} 
mas estranhas ao ofício de classicista, como o trabalho de fact-checker em uma enciclopédia de ciências sociais (1930-33) e o cargo de editor e tradutor da revista dos filósofos frankfurtianos emigrados para Nova York (1937-39). Sua iniciação em História Antiga deu-se aos vinte e poucos anos, como assistente de pesquisa em direito romano na Universidade de Columbia (1933-34) e depois como doutorando na mesma instituição (1934-50, com interrupções). O iniciante tinha a peculiaridade de não ter tido educação formal em latim ou grego, o que não o impediu de, após o aprendizado autodidata de ambos os idiomas, lecionar na área de História Antiga antes mesmo da defesa de sua tese de doutorado, em 1950.

No universo dos Estudos Clássicos britânicos, especialmente em Oxford e Cambridge, a ideia de um autodidata em línguas clássicas como Finley / Finkelstein atuar profissionalmente na área de História Antiga seria em princípio inconcebível. Como disciplina universitária, os Clássicos se institucionalizaram no século XIX (embora uma prática mais ou menos sistemática da erudição clássica fosse bem anterior a isso). Foi a primeira área dos saberes humanísticos para a qual se formalizou o Tripos, exame universitário pelo qual ainda hoje se obtém o diploma de graduação em Cambridge. O estudante que chegasse a Cambridge para cursar a graduação em Classics nos mesmos anos em que Finley era incorporado à classical scholarship local teria de conhecer previamente latim e grego. Caso houvesse crescido na Inglaterra, seu contato com essas línguas haveria provavelmente começado por volta dos 11 anos, fosse em escolas privadas de elite (chamadas public schools, não obstante pagas) ou em escolas estatais especiais (grammar schools), destinadas aos alunos de melhor desempenho nos primeiros anos de educação formal. Por volta dos 16 anos, esse estudante teria optado pelo estudo aprofundado (A-levels) das línguas clássicas nos dois últimos anos de escola. Uma vez em Cambridge, disporia normalmente de três anos para se graduar, e isso se daria em duas etapas. Os dois primeiros anos o aluno passaria a estudar fundamentalmente a gramática e a literatura greco-latinas. Ao final desse período, seus conhecimentos linguísticos seriam avaliados em um exame, o Classical Tripos Part I, cuja forma de administrar (com jornadas diversas de provas cercadas de sigilo e corrigidas por uma equipe de professores locais) e cujo caráter propedêutico (a aprovação facultava a continuidade dos estudos na segunda parte do curso) assemelhavam-se aos de uma prova

profissionais postos por restrições antissemitas fariam Moses, nascido Moses I. Finkelstein, adotar o sobrenome Finley em 1947 (cf. TOMPKINS, Daniel, op. cit., p. 13). 
brasileira de vestibular, se bem que aplicada durante os anos de graduação e por si só conferente de um degree. Os candidatos da parte I teriam de redigir ensaios a partir de tópicos ("Os deuses e os romanos") ou frases ("Tucídides, o mais moderno dos historiadores antigos") que evocassem os antigos na prova de English Essay; produziriam comentários e fariam traduções de autores antigos; comporiam diferentes modalidades de versos gregos e latinos com base em passagens de algum poeta canônico de língua inglesa; traduziriam para o inglês passagens de textos antigos em prosa; e responderiam a questões apresentadas separadamente a respeito de "história, literatura e pensamento" greco-romanos. No ano seguinte, se assim desejassem, os estudantes de Clássicos submeter-se-iam a novo exame, o Classical Tripos Part II, com estrutura semelhante, mas agora a incluir uma prova oral e a enfatizar a área de conhecimento dos Clássicos na qual o aluno houvesse optado por se aprofundar (Literatura, História, Filosofia, Arqueologia ou Filologia). ${ }^{29}$

O sucesso ou o fracasso na prova da Tripos, em especial na parte I, em razão da carga linguística, acompanharia o aluno ao longo de toda sua vida acadêmica. Os resultados eram hierarquizados em três categorias - os estudantes de "primeira classe", "segunda classe" (divisão I e II) e "terceira classe" (sendo listados em ordem alfabética dentro de cada uma das "classes"). A partir daí, to get a first, conseguir o resultado de primeira classe, implicava to be a first, isto é, ser um "primeiro". Sintomaticamente, o termo first designava, em Cambridge ou Oxford, tanto o resultado propriamente dito conquistado no exame quanto, à maneira de um título, aqueles que o obtinham. ${ }^{30}$ Mesmo fora dos ritos formais da educação clássica, havia lugar para a celebração do virtuosismo linguístico: parte da graduação dos melhores alunos de Oxford e Cambridge era dedicada a concursos de composição de versos gregos e latinos, e nos obituários dos classical scholars os prêmios e distinções alcançados em tais competições costumam figurar ao lado de doutorados honorários e outras honrarias como traços pertinentes da representação do êxito profissional.

No mundo de um classicista britânico típico, ${ }^{31}$ a exigência de domínio perfeito das línguas clássicas era um dos pilares de uma deontologia clas-

\footnotetext{
${ }^{29}$ A cada ano acadêmico, a Universidade de Cambridge publica as questões das provas aplicadas aos alunos no ano anterior. Extraio exemplos de questões propostas em maio de 1954 (Cambridge examination papers 1953-54, p. 1260-1320).

${ }^{30}$ STUBBINGS, Frank. Bedders, bulldogs $\mathcal{E}$ bedells: A Cambridge glossary. Cambridge: Cambridge University Press, 1995, p. 38 e 48.

31 Ao pensar em um tipo classicista, eu não me refiro a um classicista "médio", mas antes à construção teórica de um classicista utópico, pensado em sua pureza conceitual e passível, nesses termos,
} 
sicista. A um scholar de excelência, entretanto, não bastavam familiaridade com os textos e domínio da gramática, da sintaxe, da métrica; era também necessário responder a uma noção consagrada dos modos apropriados de aquisição e ostentação dessa competência. Com efeito, os classicistas britânicos habitualmente enquadram trajetórias intelectuais, próprias ou alheias, como percursos socioinstitucionais. São a escola de origem, a universidade frequentada (com especial referência aos colleges), ${ }^{32}$ os estágios cumpridos na Alemanha, as expedições à Itália e/ou à Grécia, o contato com mestres etc. que tornam inteligíveis o desenvolvimento e o significado de uma carreira. Tal grade de leitura mostra sua força em todas as variações de elogio erudito (necrológios, verbetes de dicionário, Festschriften etc.), em que, a pretexto de se celebrarem individualidades, são reafirmados (e disputados) os valores caros à corporação. É então que a capacidade de cultivar certos gostos e hábitos - as preferências literárias, a apreciação da "boa" música, a prática ou a admiração por esportes adequados à condição de gentleman (críquete, golfe, tênis etc.) - aparece como forma nativa de classificação de um Cambridge man ou de um Oxford man. É nesses textos ainda que a adesão a certa disciplina corporal se afigura como virtude, com referências frequentes aos registros de voz (de "barítono", de "tenor" etc.) e sua associação às qualidades de um lecturer (ou seja, de um professor-palestrante); com menções à elegância da pronúncia das palavras gregas e latinas e à capacidade declamatória dos textos clássicos; com invocações de fisionomia e compleição atravessadas por juízos morais característicos de uma vida de erudição clássica. ${ }^{33}$

As injunções sociais incidentes sobre as condutas dos classicistas e as respostas a elas racionalizadas como feitos ou malfeitos individuais eram

\footnotetext{
de ser confrontado com classicistas reais. Trata-se daquele artifício de método celebrizado (e não propriamente inventado) por WEBER, Max. A 'objetividade' do conhecimento nas ciências sociais. In: Idem. Sociologia (coletânea organizada por Gabriel Cohn). São Paulo: Ática, 1982, p. 79-127.

${ }^{32}$ Os colleges são entidades que constituem as Universidades de Cambridge e Oxford, mas que gozam de autonomia administrativa e simbólica dentro dessas instituições: cada um deles tem estatutos, ritos, hierarquia, estrutura física e recursos próprios

33 Os obituários de acadêmicos são um gênero na Inglaterra. Para a descrição do tipo classicista consultei inúmeros necrológios publicados nos Proceedings of British Academy, além de dicionários biográficos como BRIGGS, W. \& CALDER III, W. (org.). Classical scholarship. A biographical encyclopedia. Londres: Garland Publishing, 1990; e TODD, Robert (org.). Dictionary of British classicists, 3 vols. Londres: Thoemmes Continuum, 2004. Ainda que os critérios de medição acadêmica mudem, é possível encontrar invariantes de forma em todos esses textos, as quais procurei isolar aqui à maneira do que fizeram, a propósito das classificações escolares do sistema de ensino francês, BOURDIEU, Pierre E SAINT-MARTIN, Monique. Les catégories de l'entendement professoral. Actes de la Recherche en Sciences Sociales, n. 3, 1975, p. 68-93.
} 
dados relevantes no processo de incorporação às fileiras da classical scholarship daqueles que gozavam, como Finley, da condição de imigrantes em "Oxbridge" (amálgama de Oxford + Cambridge). Emigrado para a Inglaterra em um momento em que o fluxo de acadêmicos "exilados" havia arrefecido, Finley elevava-se na escala de prestígio dos historiadores da Antiguidade, mas tinha a pesar sobre si estigmas significativos. Seu vínculo profissional com a Universidade de Cambridge dava-se inicialmente por intermédio dos Clássicos (de cuja faculdade era membro docente), e nesse âmbito institucional e simbólico se forjavam os juízos efetivos sobre suas tomadas de posição como historiador de História Antiga. Ali, faltava nobreza classicista a sua extração intelectual, ou seja, aos mestres de pensamento que comporiam seu elo com a tradição disciplinar. Não é uma questão de pouca importância: as filiações estabelecidas ao longo de uma carreira são um dos recursos de medição da estatura dos classical scholars.

O silêncio quanto a suas habilidades linguísticas nos inúmeros textos de louvação a suas "vida e obra" indica a percepção de uma deficiência de formação - dê-se a isso importância maior ou menor. Trata-se de algo ocasionalmente explicitado em reminiscências sobre Finley evocadas oralmente ou registradas por escrito por seus ex-colegas e ex-alunos. ${ }^{34} \mathrm{O}$ caso não era simplesmente de alguém que não se sobressaía como linguista: havia mesmo o sentimento entre colegas de que Finley não dominava perfeitamente o grego, sendo, não obstante, um historiador do mundo clássico especializado em Grécia. Há algo em jogo que vai além de um dado pontual: a questão linguística consubstancia o entendimento difuso de outros handicaps de Finley. Num mundo em que, além da capacidade de leitura do latim e do grego e de expressão escrita nesses idiomas, a pronúncia caracteristicamente britânica anunciava o falante como membro da comunidade dos homens educados $^{35}$ é revelador que se façam referências jocosas a sua pronúncia grega

\footnotetext{
${ }^{34}$ Os registros por escrito são, em regra, posteriores a 1986, ano da morte do historiador (ver referências adiante). Quanto aos registros orais, eu pude constatá-los em conversas (com graus variáveis de formalidade) mantidas com scholars próximos a Finley nas minhas duas estadas em Cambridge para a realização desta pesquisa (novembro-dezembro de 2004 e março-dezembro de 2006). Sou grato às pessoas de Cambridge que dividiram comigo informações e impressões sobre Finley, conforme já assinalei em outro trabalho (PALMEIRA, Miguel. Moses Finley e a "economia antiga"..., op. cit.), mas evito nomeá-las aqui para não as comprometer com ideias que não são necessariamente as suas (ou que não gostariam de ver a elas associadas em público).

${ }^{35}$ Ver a esse respeito STRAY, Christopher. Classics transformed. Schools, universities and society in England, 1830-1960. Oxford: Oxford University Press, 1998, p. 126-132.
} 
"bizarra e às vezes completamente desnorteante", ${ }^{36}$ assim como a seu inglês falado em novaiorquês inconfundível, com "frases completas", distinto do estilo "mais rápido e fraturado dos britânicos". ${ }^{37}$ A sensibilidade quanto a um Finley estranho manifesta-se mesmo nas descrições físicas, quando supostamente não está em questão o "estrangeiro": "de baixa estatura, com um rosto muito enrugado e um sorriso torto cínico, ele manteve até o fim da vida o sotaque e a aparência de Edward G. Robinson, a estrela do cinema que se especializou em interpretar gângsteres". ${ }^{38}$

Seu caso não era isolado. A relação com as línguas antigas e, fundamentalmente, um tipo de conhecimento e conduta gerado em torno delas foram pontos sensíveis para scholars em situação semelhante. Em 1954, Arnaldo Momigliano, ele mesmo um classicista italiano exilado na Inglaterra desde os anos de Segunda Guerra, estimava que o malogro da passagem de um célebre classicista russo por Oxford se devesse a problemas decorrentes do domínio das línguas clássicas: "Rostovtzeff, que não tinha má opinião a respeito de si mesmo, tornou-se um caráter ainda mais agressivo sob o choque do exílio e parece não ter compreendido que os professores de Oxford em geral sabiam o grego e o latim muito melhor do que ele". ${ }^{29}$ Os mesmos critérios de apreciação da performance, mobilizados por outro autor em função de um scholar de proveniência acadêmica nobre, contam para enaltecer um classicista alemão, dono de um "olhar agudo... para elementos formais na literatura e na linguagem", de um notável "instinto para penetrar a alma de uma língua", de um "ouvido maravilhoso para nuances e idioma". ${ }^{40}$

\footnotetext{
${ }^{36}$ HORNBLOWER, Simon, op. cit., p. xv. Este texto é pleno de referências às dificuldades encontradas por Finley na Inglaterra.

37 WATSON, George. The man from Syracuse: Moses Finley 1912-1986. The Sewanee Review, v. 112, n. 1, 2004, p. 132.

${ }^{38}$ HORNBLOWER, Simon, op. cit., p. xi. Não é fortuita a comparação de nosso personagem a um ator que era igualmente de origem judaica do Leste europeu. O fato de ser judeu era certamente um marcador da posição de Finley em Cambridge. Este é mesmo um aspecto crucial de sua formação intelectual e de sua inscrição social, que exigiria um espaço maior para ser tratado adequadamente.

${ }^{39}$ Trata-se de um obituário de Rostovtzeff publicado originalmente em um periódico de Cambridge (The Cambridge Journal) e reeditado em MOMIGLIANO, Arnaldo. Problèmes d'historiographie ancienne et moderne. Paris: Gallimard, 1983, p. 424-440 (citação p. 432). Hornblower, op. cit., faz igualmente referências a Momigliano e Rostovtzeff ao invocar as "dificuldades" de Finley para se estabelecer intelectualmente na Inglaterra.

${ }^{40}$ WILLIAMS, Gordon. Eduard Fraenkel, 1888-1970. Proceedings of the British Academy, v. 56, 1970, p. 415-442 (p. 430-431 e 436 para as citações). Em termos semelhantes, será possível conferir as
} 
É razoável pensar, portanto, que o exílio tenha significado para Finley inicialmente uma espécie de marginalização, a princípio coincidente com a condição de outsider. Ele carregava marcas de alguém não educado naquele e para aquele ambiente, algo que tinha consequências para o modo como se avaliavam a obra de um scholar e o próprio scholar como obra.

\section{As virtudes dos estigmas}

Os estigmas, como chamava atenção Erwin Goffman, incutem vícios nas maneiras como os estigmatizados se veem e são vistos. Essa forma de descrédito social não corresponde, entretanto, a atributos fixos de indivíduos concretos. O estigma é um papel de identidade deteriorada desempenhado dentro de relações sociais específicas; um papel sujeito à inversão de sinais - pois as relações sociais que lhe dão suporte são passíveis de mudança - e sujeito, no limite, à invalidação - conforme se transita de uma ordem de relações para outra. ${ }^{41}$ Esse caráter relacional do estigma que ajuda a entender como a condição de outsider - com as formas por vezes discretas, mas efetivas, de desprezo que ela inspirava - moldou a conduta de Finley no exílio e contribuiu para a inflexão de sua trajetória para uma posição dominante no campo da História Antiga.

Finley era um outsider, mas não um pária. Nos 25 anos seguintes ao fim da Segunda Guerra, os Classics, um dos arranjos de relações significativas em que Finley estava inserido, passaram por mudanças de organização interna e de lugar no sistema de ensino britânico. Com o aumento do peso do financiamento público da educação, pôs-se em curso uma reorientação dos recursos das universidades para disciplinas científicas e tecnológicas, as quais atenderiam melhor às "necessidades do Estado britânico".42 Os classicistas nisso identificavam um elemento central da "crise" de suas disciplinas. O diagnóstico de um momento crítico dos Classics era alimentado pelo fato de, nas escolas, em relação ao período anterior à Segunda Guerra, menos estudantes adquirirem o conhecimento de latim e de grego além daquilo que se designava formalmente como "nível ordinário" (por oposição ao "nível avançado"

loas tecidas a esse exilado em LLOYD-JONES, Hugh. Blood for the ghosts. Classical influences in the nineteenth and twentieth century. Londres: Duckworth, 1982, p. 21-22.

${ }^{41}$ GOFFMAN, Erwin. Stigma. Notes on the management of spoiled identity. Nova York: Penguin, 1968 [1963].

${ }^{42}$ Cf. MURRAY, Keith. The development of the universities in Great Britain. Journal of the Royal Statistical Society, v. 121, n. 4, 1958, p. 391-409. 
exigido na preparação dos estudantes que viessem a se dedicar aos Clássicos na universidade). ${ }^{43} \mathrm{Na}$ ação que melhor exprime esses deslocamentos dos Clássicos, aboliu-se em 1960 a obrigatoriedade do domínio do latim como pré-requisito de ingresso nos cursos universitários de Cambridge e Oxford, esvaziando a função estratégica dos classicistas na formação da elite intelectual britânica. Reformas educacionais viriam ainda a eliminar, a partir de 1970, a exigência de conhecimento do grego para ingresso no curso de Clássicos.

As mudanças afetavam as condições de validade dos juízos que os classicistas faziam uns dos outros. O controle das línguas clássicas perdia força como esteio da profissão, ao passo que outras competências se insinuavam como legítimas. No caso da História Antiga, ganhavam espaço demandas por outro perfil de erudição, voltado para saberes mais jovens, como a Sociologia (praticamente inexistente como carreira acadêmica na Grã-Bretanha antes de 1945) e a Antropologia (esta, desde muito ancorada no establishment britânico, mas nem sempre em proximidade com historiadores da Antiguidade). Essas transformações tornavam viável a torção dos estigmas associados aos classicistas "maus linguistas". Naquele cenário em movimento, as propriedades sociais e intelectuais acumuladas por Finley ao longo de sua trajetória sujeitaram-se a uma manipulação que as erigiu em trunfos do historiador para se fazer conhecer e reconhecer como um inovador-protagonista de sua disciplina.

O momento de instabilidade dos Estudos Clássicos britânicos tornava rentável a condição de outsider, que Finley passou então a explorar sistematicamente. Nos registros mais loquazes que se tem disso, ele incorpora de bom grado a fama de quinta-coluna sociológico entre historiadores e destila, em tom de autoelogio, as diferenças entre dois tipos de formação - a dos classicistas britânicos, de caráter dito estreito, e a sua, convenientemente ampla:

Como pós-graduando na Universidade de Columbia no início dos anos 1930, eduqueime com Weber e Marx, com Gierke e Maitland em História do Direito, com Charles Beard, Pirenne e Marc Bloch. A explicação é simplesmente que eu fui formado na Faculdade de História, e esses eram alguns dos escritores cujas ideias e métodos estavam na at-

\footnotetext{
${ }^{43}$ THOMPSON, William B. Relevant or irrelevant? Classics in the curriculum today. Greece \& Rome, $2^{\mathrm{a}}$ série, v. 5, n. 2, 1958, p. 196-99.
} 
mosfera do estudo histórico, em parte nas aulas, porém ainda mais nas intermináveis conversas com outros estudantes. ${ }^{44}$

Os frutos da formação "americana" já eram visíveis na economia argumentativa de Odysseus (1954), em que a preocupação com as regularidades do mundo de Ulisses substitui a coleta ideográfica de fatos isolados. No universo acadêmico, uma reputação sólida e internacionalizada construía-se pela recepção favorável (em certos meios) das teses de Finley sobre a sociedade homérica, pela formulação inovadora do problema da escravidão no mundo antigo e pela atuação decisiva na constituição de um campo de debates sobre economia na Antiguidade. ${ }^{45}$

De outro lado, a afirmação de uma postura própria ganharia tons mais incisivos na produção de textos não acadêmicos. Isto ocorreria, por exemplo, nas dezenas de resenhas e ensaios publicados por Finley, até o início dos anos 1970, em jornais de grande circulação ou em periódicos da intelectualidade anglo-saxã. Ali, a provocação era deliberadamente usada como recurso expressivo de afirmação de suas posições (não convencionais entre classicistas, no mais das vezes). Não se tratava simplesmente de demarcação monótona de diferenças em relação aos colegas (algo que os classicistas britânicos têm como parte de sua rotina): era afronta feroz, empreendida em veículos destinados a um público cultivado de não especialistas - ou seja, fora do espaço habitualmente consentido de luta simbólica entre os praticantes da profissão. Os desacatos eram perpetrados numa fórmula que unia frases curtas de menoscabo ("Este é um dos livros mais irritantes com que jamais lidei"46) e escárnio ("Essas explicações do surgimento do Cristianismo são

\footnotetext{
${ }^{44}$ FINLEY, Moses I. New look at Ancient History for six formers. The Times, 22 de abril de 1966, p. 9.

${ }^{45}$ Já em 1965 Vidal-Naquet concebeu um primeiro balanço da obra de Finley (publicado em uma revista de Sociologia) em três chaves: mundo homérico, escravidão e economia (cf. VIDALNAQUET, Pierre. Économie et société en Grèce ancienne: l'oeuvre de Moses I. Finley. In: Idem, op. cit., p. 55-94). Ver ainda KNOX, Bernard. Triumph of a heretic. The New York Review of Books, 29 de junho de 1978, para a relevância de Finley nos estudos homéricos; JOLY, Fábio. Moses Finley e a escravidão antiga. In: CARVALHO, Alexandre (org.). A economia antiga: história e historiografia. Vitória da Conquista: Ed. UESB, 2011, p. 73-93, para a marca de Finley nas discussões sobre a escravidão (apresentada de forma crítica); e MORRIS, Ian, op. cit., para discussões gerais sobre a "economia antiga". Note-se ainda, apenas como sinalização, que tudo isso era viabilizado em meio a transformações na historiografia dos anos 1950 aos anos 1970, que intensificavam o diálogo de alguns historiadores com a Antropologia (em especial na França), entronizavam a escravidão como tema de pesquisa nobre (nos Estados Unidos, principalmente) e punham a história econômica no centro de gravidade da disciplina.

${ }^{46}$ FINLEY, Moses I. Decipherment. The New Statesman, 7 de julho de 1961.
} 
certamente originais. Não consigo pensar em nenhum outro mérito que elas tenham"); ${ }^{47}$ e tinham o agravante, para quem deles era alvo, de serem proferidos por alguém que aos poucos se arvorava em um porta-voz privilegiado da História Antiga, dentro e fora do universo acadêmico. ${ }^{48}$ Paralelamente, uma fama extra-acadêmica era alcançada pela participação regular de Finley em programas radiofônicos, depois televisivos, nos quais o historiador se distinguia tanto do sentimentalismo voltado ao culto da "glória da Grécia" e da "grandeza de Roma" quanto da redução dos Clássicos a um conhecimento estritamente técnico, produzido e consumido unicamente por classicistas profissionais. A marca dessas intervenções era tomar as experiências históricas greco-romanas clássicas como fontes para a interrogação sobre o tempo e o mundo dos ouvintes.

A verve polemista dos textos de Finley e a constituição, em meio a um processo de redefinição dos Clássicos, de um auditório solidário às concepções de História Antiga por ele abraçadas dispuseram seus colegas a tomá-lo em consideração. Duas ocasiões, impensáveis quando de sua chegada à Inglaterra, dão boa ilustração disso: a participação de Finley, em 1961, em um programa radiofônico da BBC sobre o futuro da classical scholarship, ao lado de estudiosos estabelecidos no universo social dos classicistas; ${ }^{49}$ a discussão sobre a historicidade da Guerra de Troia, publicada em 1964 no Journal of Hellenic Studies, com a intervenção de Finley servindo de mote aos textos subsequentes de classicistas de prestígio. ${ }^{50} \mathrm{O}$ reconhecimento por classicistas britânicos

\footnotetext{
${ }_{47}$ FINLEY, Moses I. Pilar of Hadrian. The Spectator, 18 de novembro de 1960, p. 786.

${ }^{48} \mathrm{O}$ trabalho de Finley como resenhista mereceria um estudo à parte. Um primeiro esforço documental e interpretativo foi feito por BEARD, Mary. Finley's journalism. In: JEW, Daniel; OSBORNE, Robin; SCOTT, Michael (org.), op. cit. p. 151-181. Levar adiante tal empreitada, incluindo no corpus documental as resenhas publicadas em periódicos especializados, exigiria o mapeamento das posições intelectuais e institucionais dos resenhados relativamente ao resenhista, de modo que se pudesse compreender a lógica que presidiu a formação do juízo erudito. Finley representa um caso interessante para pensar. Sobre ele não pesavam, na escrita desse tipo de texto, as mesmas coerções que afetavam um(a) scholar britânico, enleado(a) num circuito de lealdades constituído nos anos de formação - um circuito que não se podia romper sem consequências mais ou menos graves (ver, a esse respeito, PALMEIRA, Miguel. Moses Finley e a 'economia antiga'..., op. cit., p. 157-160).

${ }^{49}$ BOARDMAN, John; FINLEY, Moses I.; LLOYD-JONES, Hugh. The future of classical scholarship. The Listener, 30 de março de 1961, p. 562-564.

${ }^{50}$ FINLEY, Moses I.; CASKEY, John.; KIRK, Geoffrey; PAGE, Denys. The Trojan War. Journal of Hellenic Studies, v. 84, 1964, p. 1-20.
} 
de Finley como um interlocutor de fato - "temido e odiado" que fosse, ${ }^{51}$ mas, em todo caso, igualado na honra ${ }^{52}$ - o habilitava a uma legitimidade dupla: por um lado, de scholar investido do poder de incitar condutas teórico-metodológicas heterodoxas dentro da História Antiga (o comparatismo, o uso da Antropologia e da Sociologia, o esforço de forjar conceitos levando em conta os significados que os próprios antigos atrelavam a suas experiências, a construção de modelos explicativos etc.); por outro, de alguém socialmente autorizado a falar acerca da disciplina e em nome dela aos não especialistas (em um momento em que os avalistas externos eram cruciais para atestar a importância dos "Clássicos").

\section{Considerações finais}

A tendência a se idealizar a figura do intelectual exilado, a que se fez referência no início deste texto, afina-se com a atribuição de um caráter estático à ideia de exílio. Em termos típicos, a expatriação por certo será, para quem a sofre, uma passagem definidora de uma trajetória. Isto não significa que ela seja uma experiência definitiva, ultimada. O deslocamento implicado na mudança coagida de país imprime um trânsito específico no espaço social - no caso que nos interessa de perto, um trânsito específico no universo social da erudição -, mas não uma posição do "exilado" fixa e externa ao(s) grupos(s) que o acolhe(m). Finley jamais foi, na Inglaterra, um estranho completo, mas um estrangeiro no sentido de Simmel, ou seja, alguém que efetivamente faz parte do grupo em que é acolhido, ainda que sua posição nesse universo seja afetada pelo fato de não pertencer ao grupo inicialmente. ${ }^{53}$

Mesmo essa condição de estrangeiro, todavia, não se traduziu em uma constância dos termos de associação de Finley à classical scholarship britânica (para insistir no eixo de relações ao qual esteve referida a análise) e ao establishment universitário. Ela, afinal, variou no tempo: entre a chegada do

\footnotetext{
${ }^{51}$ FINLEY, Moses. Keith Hopkins interviews sir Moses Finley: October 1985 transcript. American Journal of Philology, v. 135, 2014, p. 185 (a formulação é do entrevistador, sendo aceita pelo entrevistado).

52 "Igual na honra" é a expressão que Lygia Sigaud emprega para designar a aceitação ao mesmo tempo respeitosa e tensa de um antropólogo heterodoxo de Cambridge por seus pares (trata-se de Edmund Leach, de quem, não por acaso, Finley era próximo). Cf. SIGAUD, Lygia. Apresentação. In: LEACH, E. R. Sistemas políticos da Alta Birmânia. São Paulo: Edusp, 1996, p. 42.

53 SIMMEL, Georg. The stranger. In: Idem. On individuality and social forms. Chicago: University of Chicago Press, 1971, p. 143-149.
} 
historiador a Cambridge e sua morte em 1986, a atividade dos eruditos e a posição de Finley na hierarquia de valores sustentada por tal atividade mudaram de modo concomitante e entrelaçado, conforme se procurou demonstrar acima. Outrossim, os sentidos da estrangeiração não foram sempre os mesmos. A condição de estrangeiro do historiador foi recorrentemente acionada por ele próprio e pelos pares de modo a situá-lo ora à margem da classical scholarship, ora à frente dela - em todo caso, apondo-lhe um sinal diacrítico que fazia dele um sujeito "pouco comum". ${ }^{54}$

Não é raro que estudos sobre intelectuais exilados associem a expatriação a um sentido figurado de exílio como isolamento do convívio social. É assim que, no caso de trabalhos sobre Finley, ganham peso os "anos formativos", a "formação americana", o passado supostamente obscuro etc. Nessa lógica, são os antecedentes (em relação ao período inglês) de uma vida "incomum" que explicam o desenrolar dessa vida. É como se o mundo da erudição clássica britânica sofresse os efeitos da ação desse profeta estrangeiro, sem, no entanto, exercer força alguma sobre ele. A experiência do exílio de nosso personagem, porém, assim como certamente a de muitos outros scholars e cientistas, não se explica apenas, nem principalmente, pela terra de origem, mas também pelas ligações estabelecidas na porção do mundo social em que o exilado se estabelece (o que não se passa, claro, sem que a bagagem da experiência anterior faça valer seu peso, mas contrabalançada por estruturas sociais que não são inertes). Buscou-se neste artigo, com efeito, pensar em termos das relações feitas, desfeitas e refeitas; de mudanças na produção de conhecimento sobre a Antiguidade clássica que tomam forma em conexão com as transformações dos vínculos sociais dos produtores desse conhecimento; dos laços entre as características específicas do trabalho de Finley com as reações de entusiasmo e repulsa que ele inspirou.

\footnotetext{
${ }^{54}$ A expressão é de Ricardo Di Donato: “Moses I. Finley morreu em Cambridge no dia 23 de junho de 1986, poucas horas depois do falecimento de sua esposa, Mary. Juntos, eram plenos de humanidade, em razão também de uma experiência de vida pouco comum, compartilhada por mais de cinquenta anos". (Di DONATO, Riccardo. The Moses Finley's papers: una introduzione. Opus VI-VIII, 1987-1989, p. 261 [p. 261, ênfase minha]). Recentemente, a introdução de um livro dedicado à obra do historiador sublinhou que "a biografia de Finley é diferente da de qualquer outro acadêmico do século XX." (JEW, Daniel; OBSBORNE, Robin; SCOTT, Michael. Introduction: Finley's impact: a balance sheet. In: Idem (org.), op. cit., p. 12). Ver ainda acima os excertos postos sob a rubrica "retratos de um historiador 'estrangeiro".
} 


\section{Referências bibliográficas}

BENTLEY, Michael. Modern historiography. Londres: Routledge, 1999.

BRESSON, Alain. Moses Finley. In: SALES, Véronique Sales (org.). Les historiens. Paris: Armand Colin, 2003, p. 178-79.

BOARDMAN, J.; FINLEY, M. I.; LLOYD-JONES, H. The future of classical scholarship. The Listener, 30 de março de 1961, p. 562-564.

BOURDIEU, Pierre $\mathcal{E}$ SAINT-MARTIN, Monique de. Les catégories de l'entendement professoral. Actes de la Recherche en Sciences Sociales, n. 3, 1975, p. 68-93.

BRIGGS, W. \& CALDER III, W. (org.). Classical scholarship. A biographical encyclopedia. Londres: Garland Publishing, 1990.

CARBOnELL, Charles-Olivier. Historiografia. Tradução de Pedro Jordão. Lisboa: Teorema, 1987.

DE BAETS, A. Exile and acculturation: Refugge historians since the Second World War. The International History Review, v. 28, n. 2, p. 316-349, 2006. DOI: 10.1080/07075332.2006.9641095.

Di DONATO, Ricardo. The Moses Finley's papers: una introduzione. Opus VI-VIII, 1987-1989, p. 261-264.

De STE. CROIX, G. E. M. Resenha de Studies in land and credit. The English Historical Review, v. 68, n. 268, 1953, p. 450-451.

FINLEY, M. I. Studies in land and credit in ancient Athens. The horos inscriptions. New Brunswick: Transaction Books, 1985.

. The world of Odysseus. Nova York: The New York Review of Books, 2002.

What set Homer writing? The Daily Telegraph, 8 de agosto de 1958, p. 10.

. Pilar of Hadrian. The Spectator, 18 de novembro de 1960, p. 786.

. Decipherment. The New Statesman, 7 de julho de 1961.

. New look at Ancient History for six formers. The Times, 22 de abril de 1966, p. 9.

. The ancient economy. Nova York: Penguin, 1992.

FINLEY, M. I.; CASKEY, J. L.; KIRK, G. S.; PAGE, D. L. The Trojan War. Journal of Hellenic Studies, v. 84, 1964, p. 1-20.

GERNET, Louis. Resenha de The world of Odysseus. Année Sociologique, $3^{\text {a }}$ série, v. 7, 1953-54, p. 295-297.

GOFFMAN, Erving. Stigma. Notes on the management of spoiled identity. Nova York: Penguin, 1968 [1963].

HALLET, J. P. Writing as an American in classical scholarship. In: HALLETT, J. P. \& NORTWICK, Th. Van (org.). Compromising traditions. The personal voice in classical scholarship. Londres: Routledge, 1997, p. 120-152.

HARTOG, François. La chambre de veille. Entretiens avec Felipe Brandi et Thomas Hirsch. Paris: Flammarion, 2013.

HORNBLOWER, Simon. Introduction. In: FINLEY, M. I. The world of Odysseus. Londres: The Folio Society, 2002, p. xi-xxii. 
JANES, Dominic. Finley, Moses I. In: BOYD, Kelly (org.). Encyclopedia of historians $\mathcal{E}$ historical writing, vol. 1. Londres/Chicago: Fitzroy Dearborn Publishers, 1999, p. 385-386.

JEANPIERRE, Laurent. Une opposition structurante pour l'anthropologie structurale: Lévi-Strauss contre Gurvitch, la guerre de deux exilés français aux États-Unis. Revue d'histoire des sciences humaines, v. 2, n. 11, 2004, p. 13-43. DOI: 10.3917/rhsh.011.0013.

JEW, Daniel; OSBORNE, Robin; SCOTT, Michael (org.). M. I. Finley. An ancient historian and his impact. Cambridge: Cambridge University Press, 2016.

JOLY, Fábio. Moses Finley e a escravidão antiga. In: CARVALHO, A. G. (org.). A economia antiga: história e historiografia. Vitória da Conquista: Ed. UESB, 2011, p. 73-93.

JONES, A. H. M. Resenha de Studies in land and credit. The Economic History Review, new series, v. 6, n. 3, p. 316-317, 1954.

KNOX, Bernard. Triumph of a heretic. The New York Review of Books, 29 de junho de 1978.

LLOYD-JONES, Hugh. Blood for the ghosts. Classical influences in the nineteenth and twentieth century. Londres: Duckworth, 1982.

MOMIGLIANO, Arnaldo. The Greeks and us. The New York Review of Books, 16 de outubro de 1975, p. 36-38.

. Problèmes d'historiographie ancienne et moderne. Paris: Gallimard, 1983.

MORRIS, Ian. Foreword. In: FINLEY, M. I. The ancient economy. Los Angeles: University of California Press, 1999, p. ix-xxxvi.

MURRAY, Keith. The development of the universities in Great Britain. Journal of the Royal Statistical Society, v. 121, n. 4, 1958, p. 391-409.

NAIDEN, F. S. $\mathcal{E}$ TALBERT, Richard (org.). Moses Finley in America. The making of an ancient historian. American Journal of Philology, special issue, vol. 135, n. 2, 2014.

NOVICK, Peter. That noble dream. The "objectivity question" and American historical profession. Cambridge: Cambridge University Press, 1988.

PALMEIRA, Miguel. Moses Finley e a 'economia antiga': a produção social de uma inovação historiográfica. Tese de doutorado em História Social, Programa de Pós-Graduação em História Social, USP, São Paulo, 2008.

. Arquivos pessoais e história da História: a propósito dos Finley papers. In: TRAVANCAS, Isabel; ROUCHOU, Joëlle; HEYMANN, Luciana (org.). Arquivos pessoais: reflexões multidisciplinares e experiências de pesquisa. Rio de Janeiro: Ed. FGV, 2013, p. 79-99.

SAID, Edward. Reflexões sobre o exílio. In: Idem. Reflexões sobre o exílio e outros ensaios. São Paulo: Cia das Letras, 2003.

SCHRECKER, Ellen. No ivory tower: McCarthyism and the universities. Oxford: Oxford University Press, 1986.

SHAW, Brent \& SALLER, Richard. Editors' Introduction. In: FINLEY, M. I. Economy and society in ancient Greece. Londres: Chatto \& Windus, 1981, p. ix-xxvi.

SIGAUD, Lygia. Apresentação. In: LEACH, E. R. Sistemas políticos da Alta Brimânia. São Paulo: Edusp, 1996, p. 9-45. 
SIMMEL, Georg. The stranger. In: Idem. On individuality and social forms. Chicago: University of Chicago Press, 1971, p. 143-149.

STRAY, Christopher. Classics transformed. Schools, universities and society in England, 18301960. Oxford: Oxford University Press, 1998.

STUBBINGS, Frank. Bedders, bulldogs $\mathcal{E}$ bedells: A Cambridge glossary. Cambridge: Cambridge University Press, 1995.

THOMPSON, William B. Relevant or irrelevant? Classics in the curriculum today. Greece E Rome, $2^{\text {a }}$ série, v. 5, n. 2, 1958, p. 196-99.

TODD, Robert (org.). Dictionary of British classicists, 3 vols. Londres: Thoemmes Continuum, 2004.

VIDAL-NAQUET, Pierre. La démocratie grecque vue d'ailleurs. Paris: Flammarion, 1991.

WATSON, George. The man from Syracuse: Moses Finley 1912-1986. The Sewanee Review, v. 112, n. 1, 2004, p. 131-137.

WEBER, Max. A 'objetividade' do conhecimento nas Ciências Sociais. In: Idem. Sociologia (col. organizada por Gabriel Cohn). São Paulo: Ática, 1982, p. 79-127.

WHITTAKER, C. R. Moses Finley, 1912-1986. Proceedings of the British Academy, v. 94, 1997, p. 459-472.

WILLIAMS, Gordon. Eduard Fraenkel, 1888-1970. Proceedings of the British Academy, v. 56 , p. $415-442,1970$.

Recebido: 21/02/2017 - Aprovado: 29/08/2017 